\section{Faust eller Kierkegaard?}

Lars Heslet

Fra det yderste

240 s, tab, ill. København: Bogværket, 2010. Pris DKK 375

ISBN 978-87-92420-14-5

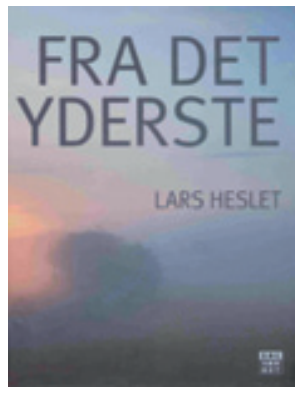

Idet jeg tar boken $\mathrm{i}$ hånden, tenker jeg: «For en bok!» Omslaget, innbindingen, papiret, typografien, presisjonen i de gjengitte kunstverkene, luften rundt teksten på sidene, rausheten i illustrasjonene, et stort noteapparat, en omfattende ordliste - alt vitner om omtanke, kvalitetsbevissthet og god råd. Denne boken er mer påkostet enn prisen tilsier. Slikt er sjelden vare i den medisinske faglitteraturen.

Boken er nemlig en medisinsk fagbok, selv om forfatteren selv kategoriserer den som «fusionsgenre» fordi den omfatter flere typer tekster. Den er skrevet av en lege for leger. Lars Heslet, professor, tidligere klinikksjef ved Intensiv Terapi Afdeling ved Rigshopitalet København og seniorforsker på samme sted til 2007, fremlegger sine faglige betraktninger fra dette stedet, fra «det yderste næs, hvor liv og død kæmper, hvor ingen standardprocedurer findes».

Heslets anliggende er sprunget ut av erfaringen fra dette neset. Han vil tematisere hva som skjer i et fag som har behandling av syke, og omsorg for døende mennesker, som oppgave, og som baserer behandlingen og omsorgen i all hovedsak på naturvitenskapelig forankret kunnskap hvor «alt der ikke kan sættes på tal - er blevet skrællet av».

Det overordnede temaet er altså spørsmålet om den medisinskfaglige kunnskapens vesen og gyldighet, og om legitimiteten av den kunnskapen som rangeres høyest: den som tillater standardiserte, evidensbaserte svar. Heslets faglige erfaring tilsier nemlig at nettopp den kunnskapen, nettopp slike svar, kan føre til at «videnskapen stiller sig mellem patienten og lægen - og spærrer for det tillidvækkende, unike møde».

Heslets filosofiske ståsted er nær Danmarks store filosof, Søren Kierkegaard, og dennes utlegninger av forholdet mellom en hjelpetrengende og en hjelper, og om betydningen av hjelperens mer-viten som en grunnleggende forutsetning for å kunne hjelpe. Denne mer-viten stiller Heslet opp mot det rådende medisinske prosjektet av kvalitetens kvantifisering for å oppnå bedre-viten. Det prosjektet innebærer, ifølge Heslet, en «faustisk» ambisjon og en fare for at «mennesket på faustisk vis sættes på formel». Som kjent var dr. Faustus, slik Goethe gjenskapte ham fra en middel- aldersk fortelling, en vitenskapsmann som ervervet høyeste kunnskap ved å gi fra seg evnen til empati, til innlevelse $i$ andres livsog erfaringsverden.

Vår danske kollega Heslet advarer mot et helsevesen der sykehus bærer preg av å være terapifabrikker med definerbare produksjonsmål, og der legerollen kan bli faustisk i betydning av «lægen som teknokrat, sælger og reservedelsekspert i det medisinske lagerrum, hvor den bedste vare på hylden er den 'evidensbaserede medicinske viden'».

Denne teksten fra spenningsfeltet

mellom bedre-viten og mer-viten bæres av en egen legitimitet: et vell av kliniske historier om betydningen av legens med-menneskelighet. Alene den omfattende delen Børn der mister er verdt hele boken. Samtidig blir forfatteren stående fast i tradisjonelle dikotomier, slik som skillet mellom det bevisste og det ubevisste. Og selv om han refererer til nyeste forskning som er i ferd med å oppheve det medisinskfaglige skillet mellom psyke og soma, går heller ikke han alltid dit «hvor den anden staar». Derfor får han aldri vite hvorfor hans kollega, dr. Wilhelm, hatet sin far så mye at han både ble storviltjeger og skjøt i stykker sitt eget ansikt - men ikke for å dø.

\section{Anna Luise Kirkengen}

Senter for helsefremmende arbeid

Akershus universitetssykehus

\section{En komikers hverdag - seriøst om bipolar lidelse}

Rigmor Galtung

Fullt lys og stummende mørke

277 s. Oslo: Cappelen Damm, 2010.

Pris NOK 329

ISBN 978-82-02-31526-9

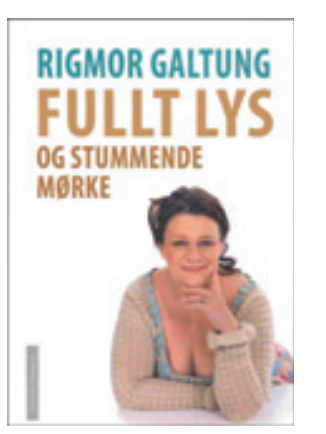

Rigmor Galtung (f. 1969) er en av landets mest kjente standup-komikere og en glitrende imitator. Første gang jeg så henne parodiere Gro, trodde jeg faktisk at det var selve landsmoderen som hadde en noe aparte fjernsynsopptreden. Fullt lys og stummende mørke er en selvbiografisk beretning om forfatterens liv med gjentakende depresjoner og hypomani. Boken er delt inn i 24 kapitler med etterord av psykiaterne John Erik Berg og Tormod Husebø.

Målgruppen er folk flest, men også fagpersoner innen psykiatrien fordi boken beskriver forfatterens opplevelser av det å motta både psykoterapeutisk og medika- mentell behandling. De første kapitlene handler om forfatterens opplevelse av foreldrenes skilsmisse da hun var 11 år, hennes erfaringer med angst allerede i ungdomstiden og hvordan hun, på tross av disse problemene, klarte å gjennomføre sin utdanning innen teaterfaget i København. Boken er delvis bygd opp kronologisk, men vi blir ikke belemret med uviktige detaljer fra forfatterens private liv.

Etter hvert utviklet hun alvorlige depresjoner og ble innlagt på psykiatrisk avdeling. Hun fikk god hjelp av psykoterapi, men også av ulike typer medikamenter. Hun beskriver behandlingsmetodene på en uvanlig nøktern og realistisk måte, her er det ingen svartmaling eller romantisering. Rigmor Galtung har på tross av sin kreative legning opplevd depresjonens stummende mørke. I perioder beskriver hun seg selv som psykotisk, og etter hvert opplevde hun at elektrokonvulsiv terapi (ECT) var den mest effektive behandlingsformen. Jeg har til gode å lese en liknende bok som på en så ærlig måte får frem både sykdommens lammende styrke og terapiens potens.

Språket bærer noen ganger preg av at boken er en subjektiv beretning, noe som kler boken godt. Hun er god til å trekke grensen mellom det private og det personlige, og hun er raus med ros til både familie og profesjonelle hjelpere. Samtidig skildrer hun også noen møter med behandlere som ikke har vært konstruktive. Hennes erfaring er at man må lytte og utvise respekt, men også kunne diagnostisere og administrere behandling. Hun beskriver ikke innleggelsene som noe hun ønsket seg, men alt i alt ga ikke sykdommen henne noe valg.

Jeg vil anbefale boken på det sterkeste. Jeg synes den bør leses både av såkalte pasienter og av terapeuter. Budskapet er at den ene posisjonen på ingen måte utelukker den andre. Depresjoner er nok i hovedsak destruktive opplevelser, men de inneholder også spirer til et dypere liv. I Rigmor Galtungs fremstilling blir denne innsikten klar uten at den får romantikkens slør. Det er noen ganger fullt lys også i stummende mørke.

\section{Tor Ketil Larsen}

Psykiatrisk klinikk

Stavanger universitetssjukehus 